\title{
Transformation of Helicobacter pylori by chromosomal metronidazole resistance and by a plasmid with a selectable chloramphenicol resistance marker
}

\author{
Ying Wang, $\dagger$ K. Pieter Roos and Diane E. TAYloR* \\ Department of Medical Microbiology and Infectious Diseases, University of Alberta, Edmonton, Alberta, \\ Canada T6G $2 \mathrm{H7}$
}

(Received 11 March 1993; revised 26 April 1993; accepted 4 May 1993)

\begin{abstract}
Most strains of Helicobacter pylori are naturally competent for uptake of chromosomal DNA. Transformation frequencies for streptomycin resistance or rifampicin resistance markers ranged from $1 \times 10^{-4}$ to $1 \times 10^{-3}$ per viable cell using a plate transformation procedure. Transformation of a metronidazole resistance marker (Mtr) was demonstrated when either a laboratory-derived mutant or a $\mathbf{M t r}^{\mathrm{R}}$ clinical isolate were used as the source of donor DNA. Mtr ${ }^{\mathrm{R}}$ was transformed at a frequency of $3 \times 10^{-5}$ per viable cell. All $H$. pylori strains tested produce large amounts of DNAase, which may reduce DNA available for transformation. Four $H$. pylori plasmids were isolated. DNA fragments from $H$. pylori plasmids were deleted or rearranged when cloned in pUC19 and propagated in Escherichia coli DH5 $\alpha$. An H. pylori plasmid, pUOA26 which contained a chloramphenicol resistance determinant from Campylobacter coli, was constructed in $H$. pylori. This plasmid could be successfully introduced by natural transformation only into $\mathrm{H}$. pylori recipients which contained a homologous resident plasmid. Transformation of pUOA26 into plasmid-free cells of $\boldsymbol{H}$. pylori was achieved by electroporation. Transformation frequencies were $1 \times 10^{-4}$ transformants per viable cell when plasmid DNA was isolated from the same strain; however, introduction of pUOA26 DNA derived from $H$. pylori 8091 into a different $H$. pylori strain, NCTC 11639, resulted in transformation at much lower frequencies $\left(\leqslant 1 \times 10^{-7}\right.$ per viable cell). Changes in plasmid restriction patterns were also noted when pUOA26 was isolated from $H$. pylori NCTC 11639, suggesting the presence of at least two different DNA restriction and modification systems in $H$. pylori which may interfere with uptake of plasmid DNA.
\end{abstract}

\section{Introduction}

Helicobacter pylori, a Gram-negative microaerophilic bacterium, has been recognized as a major factor in the development of gastritis and ulcer disease in man (Dick, 1990). Little information is available concerning the genetics of $H$. pylori, and only a few genes have been cloned and sequenced (for a review, see Taylor, 1992). Nedenskov-Sorensen et al. (1990), however, observed transformation to streptomycin resistance in 22 out of 25 $H$. pylori strains tested. Kleanthous et al. (1991) characterized a $1.5 \mathrm{~kb}$ plasmid, pHPK255, from $H$. pylori. Nucleotide sequence analysis revealed that ORF1 of pHPK 255 has significant similarities to Rep proteins of some plasmids from Gram-positive bacteria which replicate via the 'rolling-circle' mechanism. However, as

*Author for correspondence. Tel. +1 4034924777 ; fax +1 403492 7521; e-mail userdeht@mts.ucs.

$\dagger$ Present address: Biotechnology Research Institute, 6100 Royalmount Avenue, Montreal, Quebec, Canada H4P 2R2. yet no gene transfer systems have been developed for genetic analysis and in vitro DNA manipulation in $H$. pylori.

In this study, we confirmed that most $H$. pylori strains are naturally transformable and constructed an $H$. pylori plasmid with a chloramphenicol resistance $\left(\mathrm{Cm}^{\mathrm{R}}\right)$ marker, which is expressed in $H$. pylori. We also obtained evidence for restriction and modification of DNA in $H$. pylori.

\section{Methods}

Strains, plasmids and culture conditions. The strains of Helicobacter species used in this study are listed in Table 1. Most of these strains were clinical isolates from the University of Alberta hospital (Taylor et al., 1987). Campylobacter coli UA585 (Wang \& Taylor, 1990a) and Escherichia coli DH5 $\alpha$ (Sambrook et al., 1989) were also used. Plasmids used and constructed in this study are shown in Table 1. Plasmids employed were pUC19 derivatives (Yanisch-Perron et al., 1985). Plasmid pHPK255 was kindly provided by H. Kleanthous (Kleanthous et al., 1991). Plasmid pUOA23 was constructed by inserting a $920 \mathrm{bp}$ BssHII-EcoRI DNA fragment from pUOA20, containing the $C$. coli $\mathrm{Cm}^{\mathrm{R}}$ gene (Wang \& Taylor, 1990 $b$ ) which had been blunt-ended with 
Table 1. Helicobacter strains and plasmids used in this study

\begin{tabular}{|c|c|c|c|}
\hline $\begin{array}{l}\text { Strain or } \\
\text { plasmid }\end{array}$ & $\begin{array}{l}\text { Resistance } \\
\text { phenotype* }\end{array}$ & $\begin{array}{c}\text { Plasmid } \\
\text { content } \\
\text { (size, kb) } \dagger\end{array}$ & $\begin{array}{l}\text { Source or } \\
\text { reference }\end{array}$ \\
\hline \multicolumn{4}{|l|}{ H. pylori } \\
\hline UA759 & - & ND & H. Lior, Canada \\
\hline UA802 & - & ND & Canada \\
\hline UA831: & - & ND & Canada \\
\hline UA841 & - & pUA841 (2.7) & Canada \\
\hline UA875 & - & $\begin{array}{l}\text { pUA875A (5.5) } \\
\text { pUA875B (ca 15) }\end{array}$ & Canada \\
\hline UA877 & - & ND & Canada \\
\hline UA883 & $\mathrm{Mtr}^{\mathrm{R}}$ & pUA883 ( $c a$ 12) & Canada \\
\hline UA889 & - & ND & Canada \\
\hline $\mathrm{C} 2 \mathrm{R}$ & $\mathrm{Mtr}^{\mathrm{R}}$ & ND & $\begin{array}{l}\text { J. A. Washington, } \\
\text { USA (Knapp et } \\
\text { al. 1991) }\end{array}$ \\
\hline NCTC 11639 & - & ND & UK \\
\hline JAH60 & - & ND & Canada \\
\hline JAH60 $\left(\mathrm{Mtr}^{\mathrm{R}}\right)$ & $\mathrm{Mtr}^{\mathbf{R}}$ & ND & This study \\
\hline $8091 \ddagger$ & $\mathrm{Mtr}^{\mathrm{R}}$ & ND & Glaxo, UK \\
\hline 8091R & $\mathrm{Mtr}^{\mathrm{R}} \operatorname{Rif}^{\mathrm{R}} \mathrm{Str}^{\mathrm{R}}$ & ND & This study \\
\hline \multicolumn{4}{|l|}{ H. mustelae } \\
\hline F251 & NT & NT & Glaxo, UK \\
\hline F251 $\left(\mathrm{Rif}^{\mathrm{R}}\right)$ & $\mathrm{Rif}^{\mathrm{R}}$ & NT & Glaxo, UK \\
\hline \multicolumn{4}{|l|}{ Plasmid } \\
\hline pUC19 & $\mathrm{Ap}^{\mathrm{R}}$ & $(2 \cdot 7)$ & $\begin{array}{l}\text { Yanisch-Perron et } \\
\text { al. (1985) }\end{array}$ \\
\hline pHPK255 & - & $(1 \cdot 5)$ & $\begin{array}{l}\text { Kleanthous et al. } \\
\text { (1991) }\end{array}$ \\
\hline pUOA20 & $\mathrm{Cm}^{\mathrm{R}}$ & $(4 \cdot 8)$ & $\begin{array}{l}\text { Wang \& Taylor } \\
(1990 a, b)\end{array}$ \\
\hline pUOA23 & $A p^{R} C^{R}$ & $(3 \cdot 6)$ & This study \\
\hline pUOA26 & $\mathrm{Cm}^{\mathrm{R}}$ & $(4 \cdot 5)$ & This study \\
\hline
\end{tabular}

*Abbreviations: $\mathrm{Ap}^{\mathrm{R}}$, ampicillin resistance; $\mathrm{Cm}^{\mathrm{R}}$, chloramphenicol resistance; $\mathrm{Mtr}^{\mathrm{R}}$, metronidazole resistance; $\mathrm{Rif}^{\mathrm{R}}$, rifampicin resistance; $\mathrm{Str}^{\mathrm{R}}$, streptomycin resistance. Most of the $H$. pylori strains were also tested for chloramphenicol, kanamycin and tetracycline sensitivity, and none were resistant. -, Sensitive to all antibiotics tested; NT, not tested.

$\dagger$ ND, Not detected by the modified alkaline lysis method; NT, not tested.

$\ddagger$ These strains are able to undergo limited growth in a $7 \% \mathrm{CO}_{2}$ incubator.

DNA polymerase Klenow fragment, into the blunt-ended AatII site of pUC19. Plasmid pUOA26, which consisted of an $H$. pylori plasmid containing the $C$. coli $\mathrm{Cm}^{\mathrm{R}}$ gene, was also constructed in this study (Fig. 3).

$H$. pylori and $H$. mustelae strains were cultured in BHI-YE $(3.5 \%$, $\mathrm{v} / \mathrm{v}$, Brain Heart Infusion, $0.2 \%$ yeast extract, $5 \%$, w/v, horse serum) at $36{ }^{\circ} \mathrm{C}$ in anaerobic jars containing gas generating kits (Oxoid) which provide a residual concentration of about $6 \%(\mathrm{v} / \mathrm{v}) \mathrm{O}_{2}$ and $10 \%(\mathrm{v} / \mathrm{v})$ $\mathrm{CO}_{2}$. Cold plates or broth were inoculated with $\mathrm{H}$. pylori and placed immediately in jars. Although a few $\mathrm{H}$. pylori strains were able to grow in a $37^{\circ} \mathrm{C}$ incubator containing $7 \% \mathrm{CO}_{2}$, cells became non-viable in approximately $4 \mathrm{~d}$. C. coli was grown in Mueller-Hinton medium at $37^{\circ} \mathrm{C}$ with $7 \% \mathrm{CO}_{2}$, whereas $E$. coli was grown in $\mathrm{LB}$ (Luria-Bertani) broth (Sambrook et al., 1989) at $37^{\circ} \mathrm{C}$. When necessary, the medium was supplemented with ampicillin $\left(100 \mu \mathrm{g} \mathrm{ml}^{-1}\right)$, chloramphenicol $\left(10-15 \mu \mathrm{g} \mathrm{ml}^{-1}\right)$, metronidazole $\left(16 \mu \mathrm{g} \mathrm{ml}^{-1}\right)$, rifampicin $\left(20 \mu \mathrm{g} \mathrm{ml}^{-1}\right)$ or streptomycin $\left(10-20 \mu \mathrm{g} \mathrm{ml}^{-1}\right)$.

Plasmid and chromosomal DNA isolation. Chromosomal DNA and $E$. coli plasmid DNA were prepared by conventional methods (Sambrook et al., 1989). H. pylori plasmid DNA extractions were carried out by method of Birnboim \& Doly (1979) with the following modifications. Cells from plate cultures were washed once in TES (10 mM-Tris, $\mathrm{pH} \mathrm{8.0,1} \mathrm{mM-EDTA,} 100 \mathrm{~mm}-\mathrm{NaCl}$ ) and were suspended in solution I (40 mM-Tris, pH 7.9, 2.5 mM-EDTA, $15 \%$, w/v, sucrose) without the addition of lysozyme. Plasmid DNA was purified by the 'Magic miniprep' (Promega) procedure, or by caesium chlorideethidium bromide density gradient centrifugation. $H$. pylori cells collected from plate cultures gave higher yields of plasmid DNA than those from broth cultures.

Transformation by natural competence. $H$. pylori transformation was performed on an agar surface unless otherwise specified. Briefly, fresh recipient cells $(30 \mathrm{~h}$ growth on BHI-YE agar) were plated at high density on BHI-YE agar on areas of $8-10 \mathrm{~mm}$ in diameter, and incubated for $5 \mathrm{~h}$. Aliquots of DNA [0.3-2 $\mu \mathrm{g}$ in $8 \mu \mathrm{l} \mathrm{BHI-YE}$ broth or TE buffer (10 mM-Tris, 1 mM-EDTA, $\mathrm{pH} 8.0)$ ] were spotted directly onto the inoculated agar, and incubation was continued for $12 \mathrm{~h}$. The DNA-treated cells were scraped up with a loop in a small volume of TE buffer and were then spread on BHI-YE agar containing appropriate antibiotics with or without dilution, to select transformants. Transformation frequences were calculated from the number of transformants divided by the number of viable cells at the time of plating on selective agar. Some transformation experiments were performed in 
broth using the procedure described by Nedenskof-Sorensen et al. (1990). In these experiments 5-10 $\mu \mathrm{g}$ DNA ml${ }^{-1}$ was added. Transformation frequencies were calculated as described above. C. coli transformation was performed on Mueller-Hinton agar as described previously (Wang \& Taylor, 1990a).

Detection of DNA hydrolysis. The production of DNAase by $H$. pylori cells was detected using toluidine blue-DNA agar as described by Lior \& Patel (1987).

DNAase activity was also assayed using ${ }^{32}$ P-labelled DNA. $\lambda$ DNA $(1 \mu \mathrm{g})$ was digested with HindIII, end-labelled with $\left.{ }^{32} \mathrm{P}\right] \mathrm{dCTP}$, and added to $0.3 \mathrm{ml} H$. pylori UA831 cells in BHI-YE broth ( $\mathrm{ca} 10^{8}$ cells $\mathrm{ml}^{-1}$ ). The culture was incubated at $37^{\circ} \mathrm{C}$ in $7 \% \mathrm{CO}_{2}$. Samples were withdrawn and transferred to ice, and EDTA was added to a concentration of $25 \mathrm{~mm}$. The samples were extracted with phenol/chloroform. Five microlitres of each supernatant was subjected to electrophoresis in a $1.2 \%$ agarose gel.

DNA labelling, Southern hybridization and detection of single-stranded plasmid DNA. Restricted plasmid DNA was excised from low-meltingpoint agarose gel and radiolabelled with $\left[\alpha{ }^{32} \mathrm{P}\right] \mathrm{dCTP}$ by the standard random primer labelling method (Feinberg \& Vogelstein, 1983). Southern transfer (Sambrook et al., 1989) was carried out with pure nitrocellulose membrane (Bio-Rad). Hybridization was carried out in $5 \times \mathrm{SSC}(1 \times \mathrm{SSC}$ is $0.15 \mathrm{M}-\mathrm{NaCl}, 0.015 \mathrm{M}$-sodium citrate, $\mathrm{pH} 7.0)$, $25 \%(\mathrm{w} / \mathrm{v})$ formamide, $50 \mu \mathrm{g}$ denatured salmon sperm DNA ml${ }^{-1}$, $5 \times$ Denhardt's solution and ${ }^{32} \mathrm{P}$-labelled DNA at $37^{\circ} \mathrm{C}$. The filter was washed under low-stringency conditions: four times in $2 \times \mathrm{SSC}$, $0.1 \%$ SDS at $45^{\circ} \mathrm{C}$ for $30 \mathrm{~min}$ each, and exposed to X-ray film for $4 \mathrm{~h}$. The same filter was then washed under high-stringency conditions: two times in $1 \times \mathrm{SSC}, 0.1 \% \mathrm{SDS}$ at $50^{\circ} \mathrm{C}$ for $15 \mathrm{~min}$ each, and two times in $0.1 \times \mathrm{SSC}, 0.5 \% \mathrm{SDS}$ at $63{ }^{\circ} \mathrm{C}$ for $2 \mathrm{~h}$ and $30 \mathrm{~min}$, respectively, and exposed overnight.

The method used to detect single-stranded plasmid DNA by Southern hybridization was described by te Riele et al. (1986). Total DNA was extracted from exponential phase bacteria. The DNA was then either denatured or left non-denatured before transfer to nitrocellulose and hybridization to pUOA26 as described above.

Electroporation of $H$. pylori. Electroporation of $H$. pylori was performed using the Gene Pulser electroporation apparatus (Bio-Rad) by a method similar to that used for transformation of $C$. jejuni (Miller et al., 1988). Plate cultures were used to inoculate BHI-YE plates. After 18-24 h incubation, cells were collected in $30 \mathrm{ml}$ cold double-distilled water and washed again in $20 \mathrm{ml}$ cold $10 \%(\mathrm{v} / \mathrm{v})$ glycerol. The pellet was resuspended in 1 or $2 \mathrm{ml} 10 \%$ glycerol. Plasmid DNA $(0.5-2 \mu \mathrm{g}$ in 5-10 $\mu 1$ TE buffer) was mixed with $0.2 \mathrm{ml}$ cell suspension. The mixture was transferred into a prechilled $0.2 \mathrm{~cm}$ cuvette, and subjected to singlepulse electroporation of initial voltage $2.5 \mathrm{kV}\left(12.5 \mathrm{kV} \mathrm{cm}^{-1}\right), 25 \mu \mathrm{F}$ and $600 \Omega(\tau=12.5 \mathrm{~ms})$ in parallel. A sample of $10 \mu \mathrm{l}$ was diluted in cold BHI-YE broth and plated on BHI-YE agar to determine the number of cells that survived electroporation. The suspension was transferred onto a cold plate and incubated for $12 \mathrm{~h}$ at $36^{\circ} \mathrm{C}$. The cells were then transferred onto selective media and incubated for $5 \mathrm{~d}$ to allow the growth of transformants.

For long-term storage, competent cells in $10 \%$ glycerol were frozen in dry ice and stored at $-90^{\circ} \mathrm{C}$ until needed. Frozen cells were thawed on ice and used immediately for electroporation.

\section{Results}

\section{Isolation of antibiotic-resistant mutants}

Spontaneous $\mathrm{Str}^{\mathrm{R}}$ mutants of $H$. pylori 8091 were isolated by plating fresh 8091 cells onto BHI-YE agar containing streptomycin $\left(10 \mu \mathrm{g} \mathrm{ml}^{-1}\right)$. The MIC of streptomycin for these mutants was greater than $1000 \mu \mathrm{g} \mathrm{ml}^{-1}$. A Str ${ }^{\mathrm{R}} \mathrm{Rif}^{\mathrm{R}}$ double mutant (designated 8091R) was isolated from one of these $\operatorname{Str}^{R}$ mutants. The MIC of rifampicin for this mutant was greater than $100 \mu \mathrm{g} \mathrm{ml}^{-1}$. Mutation frequencies for both $\mathrm{Str}^{\mathrm{R}}$ and $\mathrm{Rif}^{\mathrm{R}}$ in this strain were about $10^{-8}$ per viable cell. Except for $8091, \mathrm{Str}^{\mathrm{R}}$ or $\mathrm{Rif}^{\mathrm{R}}$ spontaneous mutants were not obtained using any of eight other $H$. pylori strains. Although several strains were tested for metronidazole resistance, no $\mathbf{M t r}^{\mathrm{R}}$ mutants were obtained, except from $H$. pylori JAH60. The mutation frequency for $\mathrm{Mtr}^{\mathrm{R}}$ in this strain was approximately $10^{-3}$ per cell when plated on BHI-YE agar containing metronidazole $\left(16 \mu \mathrm{g} \mathrm{ml}^{-1}\right)$. The MIC of this $\mathrm{Mtr}^{\mathrm{R}}$ mutant was $60 \mu \mathrm{g} \mathrm{ml}^{-1}$.

\section{Natural transformation of $H$. pylori by chromosomal markers}

Using $H$. pylori 8091R DNA as donor to test for natural competence in broth cultures, we found some $H$. pylori strains which were transformable. The maximum transformation frequency for the chromosomal markers $\left(\mathrm{Str}^{\mathrm{R}}\right.$ or $\operatorname{Rif}^{\mathrm{R}}$ ) was $1 \times 10^{-6}$ per viable cell when broth cultures were used. However, when tested on plate cultures, natural transformation was demonstrated for 10 out of 12 strains. Transformation frequencies for $\mathrm{Str}^{\mathrm{R}}$ or $\mathrm{Rif}^{\mathrm{R}}$ markers ranged from $1 \times 10^{-4}$ to $1 \times 10^{-3}$ per viable cell (Table 2).

Transformation of $H$. pylori by a metronidazole resistance marker was also demonstrated. Both a laboratory-derived mutant of $H$. pylori JAH60 $\left(\mathrm{Mtr}^{\mathrm{R}}\right)$ and a $\mathrm{Mtr}^{\mathrm{R}}$ clinical isolate C2R (Knapp et al., 1991) were used as the source of donor DNA. Transformation frequencies for the $\mathrm{Mtr}^{\mathrm{R}}$ marker were about one-tenth those for either $\mathrm{Rif}^{\mathrm{R}}$ or $\mathrm{Str}^{\mathrm{R}}$ markers (Table 2).

To optimize conditions for transformation of $H$. pylori using 8091R DNA as the donor and JAH60 as the recipient, DNA was added to a JAH60 plate culture at $0-16 \mathrm{~h}$ after initial inoculation. Transformants were obtained at frequencies ranging from $4 \times 10^{-5}$ to $3 \times 10^{-4}$ per viable cell. Highest transformation frequencies were found when DNA was added at 5 and $10 \mathrm{~h}$.

In some naturally transformable bacteria, such as Haemophilus influenzae, competence develops when cell division is blocked under conditions that allow continued protein synthesis (Stewart \& Carlson, 1986). Therefore, transformation experiments were performed using three different media, BHI-YE agar, Mueller-Hinton agar and supplemented minimal medium agar (M9CA, Sambrook et al., 1989). The latter two media do not support growth of $H$. pylori JAH60. Transformation efficiencies decreased dramatically using Mueller-Hinton and M9CA agar from approximately $3 \times 10^{-4}$ to $1.4 \times 10^{-5}$ and $8 \times 10^{-6}$ transformants per viable cell, respectively. These 
Table 2. Natural transformation of $H$. pylori with homologous chromosomal DNA

\begin{tabular}{llccc}
\hline & & \multicolumn{3}{c}{$\begin{array}{c}\text { Transformation frequency } \\
\text { per viable cell }\end{array}$} \\
\cline { 3 - 5 } Donor & \multicolumn{1}{c}{ Recipient } & $\operatorname{Rif}^{\mathbf{R}}$ & $\operatorname{Str}^{\mathrm{R}}$ & $\mathrm{Mtr}^{\mathrm{R}}$ \\
\hline H. pylori & & & & \\
$8091 \mathrm{R}$ & $\mathrm{UA841} \dagger$ & $4.0 \times 10^{-4}$ & $4.0 \times 10^{-4}$ & - \\
JAH60 $\left(\mathrm{Mtr}^{\mathrm{R}}\right)$ & $\mathrm{UA841}$ or NCTC 11639 & - & - & $3.0 \times 10^{-5}$ \\
C2R & UA841 or NCTC 11639 & - & - & $3.0 \times 10^{-5}$ \\
\hline \hline
\end{tabular}

* Transformation was performed three times on BHI-YE agar. Transformation frequencies were determined by spotting $1 \mu \mathrm{g}$ DNA on to agar inoculated with $H$. pylori cells. The plate was incubated for $12 \mathrm{~h}$, then about $1 \times 10^{7}$ cells were scraped off the agar and plated onto selective medium. Cell number was determined from plate counts in several representative experiments. -, Not applicable.

$\dagger$ Transformation frequencies of $\mathrm{Rif}^{\mathrm{R}}$ and $\mathrm{Str}^{\mathrm{R}}$ markers were similar to UA841 when using UA759, UA802, UA831, UA875, UA877, UA883, JAH60, NCTC 11639 and 8091 as hosts. Similar transformation frequencies were obtained, although transformation frequencies for the $\mathrm{Mtr}^{\mathrm{R}}$ marker were not tested in these strains.

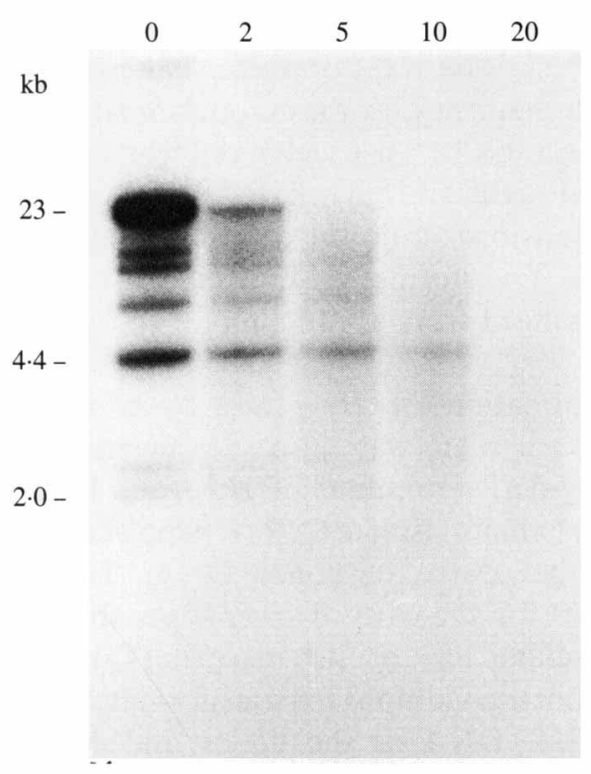

Fig. 1. Degradation of DNA by $H$. pylori. $H$. pylori UA831 cells were incubated with $H$ indIII-cut, ${ }^{32} \mathrm{P}$-labelled $\lambda$ phage DNA. Samples were withdrawn at the indicated time intervals $(\mathrm{min})$ and run in a $1.2 \%$ $(w / v)$ agarose gel.

results demonstrate that active metabolism in the recipient cell is required for transformation. Transformation efficiencies were decreased by one-half to onethird when cultures were incubated with DNA in a $7 \% \mathrm{CO}_{2}$ incubator instead of in a jar containing $6 \% \mathrm{O}_{2}$ and $10 \% \mathrm{CO}_{2}$ (data not shown). Therefore, actively growing cells appeared more competent than slow growing or static cultures.

The $H$. mustelae strain F251 was also transformed to Rif $^{R}$ at a frequency of approximately $1 \times 10^{-6}$ transformants per viable cell using F251 (Rif $\left.{ }^{\mathbb{R}}\right)$ DNA as

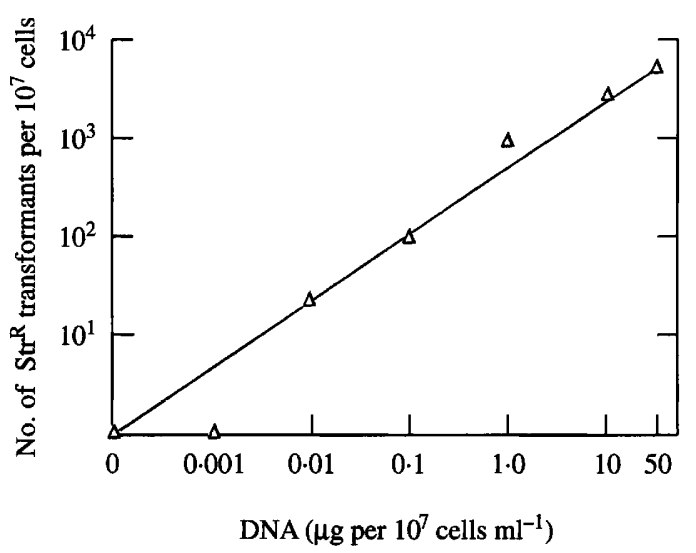

Fig. 2. Dependence of transformation frequency on the concentration of donor DNA. The recipient was UA831, and the donor DNA was from 8091R. Transformation was performed in BHI-YE broth. DNA was added at the indicated concentrations. $\operatorname{Str}^{R}$ transformants were selected after $12 \mathrm{~h}$ incubation.

the donor. No interspecies transformation was observed between an $H$. mustelae $\mathrm{F} 251$ recipient and $\mathrm{Str}^{\mathrm{R}} H$. pylori DNA, nor between a Campylobacter coli recipient and $\mathrm{Str}^{\mathrm{R}} H$. pylori DNA.

\section{DNAase activity of $H$. pylori}

All $H$. pylori strains listed in Table 1 produced large amounts of DNA-hydrolysing activity on toluidine blueDNA agar. This activity of $H$. pylori was examined using $\lambda$ phage DNA (Fig. 1). Most of the ${ }^{32}$ P-labelled DNA disappeared within 2 min. Hydrolysis of plasmid DNA was also examined. Five micrograms of $E$. coli plasmid pUC19 or $H$. pylori plasmid pUOA26 were added to $100 \mu \mathrm{l} \mathrm{H}$. pylori 8091 broth culture $\left(\right.$ ca $5 \times 10^{7}$ cells ml $\left.^{-1}\right)$, 
and incubated at $37^{\circ} \mathrm{C}$. Both plasmids were completely linearized in $3 \mathrm{~min}$, and most of the DNA was digested and disappeared from the agarose gel in $20 \mathrm{~min}$. Plasmids pUC19 or pUOA26, which had been cut with EcoRI, were digested a little faster than their supercoiled forms.

The transformation frequencies of $H$. pylori UA831 to $\mathrm{Str}^{\mathrm{R}}$ by $8091 \mathrm{R}$ DNA increased linearly with the donor DNA concentration. The linear plot demonstrates that the DNA concentration was always below the saturation level (Fig. 2). In another experiment, the number of Rif $^{\mathrm{R}}$ transformants obtained with $5 \mu \mathrm{g}$ DNA was 12 -fold higher than that obtained using $0.5 \mu \mathrm{g}$ DNA which suggests a similar conclusion regarding the saturation level. However, Fig. 2 cannot be regarded as a true dose response curve (i.e. transformation frequency versus DNA concentration) but is rather a measurement of the DNA that escaped the DNA-hydrolysing activity of $H$. pylori.

\section{DNA uptake and competition}

DNA from $H$. pylori JAH60 and 8091, $C$. jejuni UA466 and $E$. coli was labelled with ${ }^{32} \mathrm{P}$ as described previously (Wang \& Taylor, 1990a), and used to examine DNA uptake by $H$. pylori 8091 and UA831 either in broth cultures or on plate cultures (approximately $0 \cdot 1 \mu \mathrm{g}$ DNA per $10^{8}$ cells). Less than $0.5 \%$ of the input radioactivity was found to be associated with the cells $20 \mathrm{~min}$ after the addition of DNA. Similar quantities of radioactivity from both homologous and heterologous DNA were found to be associated with $H$. pylori cells.

Transformation of UA831 with $0.4 \mu \mathrm{g} 8091 \mathrm{R}$ DNA was performed in the presence of five times the concentration of competing DNA from $H$. pylori JAH60 and $8091, C$. jejuni and $E$. coli. The competing DNA of all three species reduced the transformation frequency by five- to sixfold. Therefore, heterologous DNA competed at almost the same extent with $H$. pylori DNA for uptake.

\section{Construction of $H$. pylori plasmid pUOA26}

A cryptic plasmid, pUA841, was isolated from $H$. pylori strain UA841, and purified using Magic minipreps (Promega). The plasmid was digested by HindIII to produce a single fragment of $2.7 \mathrm{~kb}$ or was partially digested by $E c o$ RI. The restricted plasmid was ligated to $E c o$ RI- or HindIII-cut pUC19, and used to transform $E$. coli DH5 $\alpha$. Six recombinant plasmids were obtained which contained insertions of various sizes. DNA rearrangements were also observed when cloning pUA883 in E. coli.

A recombinant plasmid containing $3 \mathrm{~kb}$ of pUA841derived DNA inserted at the EcoRI site of pUC19 was

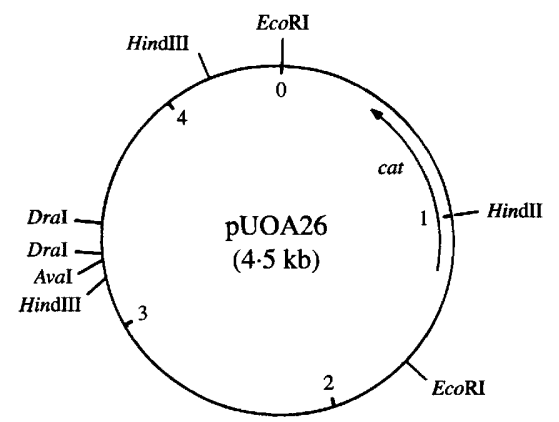

Fig. 3. Physical map of $H$. pylori plasmid pUOA26 isolated from $H$. pylori 8091 . Values are in $\mathbf{k b}$.

digested with EcoRI and ligated to EcoRI-cut pUOA23 which contains a chloramphenicol resistance marker (cat) originating from C. coli (Wang \& Taylor, 1990b). The mixture was used to transform UA841(pUA841) and $\mathrm{Cm}^{\mathrm{R}}$ transformants were obtained (180 transformants per $0.3 \mu \mathrm{g} \mathrm{DNA}$ ). Plasmids from four transformants were isolated, all contained both pUA841 and a recombinant plasmid containing the cat gene. pUA841 was apparently a stable high-copy-number plasmid, whereas the recombinant $\mathrm{Cm}^{\mathrm{R}}$ plasmids were relatively unstable. All four transformants became susceptible to chloramphenicol after growth on non-selective media. A small recombinant plasmid $(4.5 \mathrm{~kb})$ was chosen to transform $H$. pylori 8091 by electroporation using the Gene Pulser (Bio-Rad) in a $0.4 \mathrm{~cm}$ cuvette at $2.5 \mathrm{kV}$ $\left(6.25 \mathrm{kV} \mathrm{cm}^{-1}\right)$ and $25 \mu \mathrm{F}$. Twelve $\mathrm{Cm}^{\mathrm{R}}$ transformants were obtained (ca $0.5 \mu \mathrm{g}$ DNA and $1 \times 10^{7}$ recipient cells). Each contained a single plasmid which was named pUOA26.

Plasmid pUOA26 isolated from $H$. pylori 8091 could be cut with $A v a \mathrm{I}, D r a \mathrm{I}, H i n \mathrm{dIII}, M b o \mathrm{I}$ and Sau3AI (Fig. 3). The plasmid was cleaved by EcoRI into two fragments. The DNA was not cut by the following 22 restriction enzymes tested: $A c c \mathrm{I}, A p a \mathrm{I}, B a m \mathrm{HI}, B g I \mathrm{II}$, $B s s \mathrm{HII}, C l a \mathrm{I}, E c o \mathrm{RV}, H i n c I I, H p a \mathrm{I}, K p n \mathrm{I}, M s p \mathrm{I}, N c o \mathrm{I}$, NdeI, PstI, SalI, ScaI, SmaI, SphI, SspI, SstI, XbaI, $X h o I$. This list includes $C l a \mathrm{I}$ which has a recognition site within the cat ORF (Wang \& Taylor, 1990b). The chromosomal DNAs from $H$. pylori 8091, JAH60 and UA883 were also found to be resistant to ClaI digestion. However, the restriction sites shown in Fig. 3 and the results described above applied only to experiments in which pUOA26 was isolated from $H$. pylori 8091 . Isolation of the pUOA26 plasmid from $H$. pylori strain NCTC 11639 resulted in acquisition of an EcoRI site at approximately $2.9 \mathrm{~kb}$ (Fig. 3) and loss of two HindIII sites. Additional sites for both $S m a \mathrm{I}$ and $S s t \mathrm{I}$ were also acquired. Since the relative positions of all original sites remaining was not altered and the plasmid size was unchanged, we concluded that these changes were due to 
Table 3. Natural transformation of $H$. pylori by plasmid $D N A$

\begin{tabular}{|c|c|c|}
\hline Donor & Recipient & $\begin{array}{l}\text { Transformation } \\
\text { frequency } \\
\text { per viable } \\
\text { cell* }\end{array}$ \\
\hline $\begin{array}{l}\text { pUA841:pUOA23 } \\
(E c o \text { RI }) \dagger\end{array}$ & $\begin{array}{l}\text { UA841(pUA841) } \\
\text { UA831, } 8091 \text { or JAH60 }\end{array}$ & $\begin{array}{r}2.0 \times 10^{-5} \\
<1.0 \times 10^{-8}\end{array}$ \\
\hline pUOA26 & $\begin{array}{l}\text { UA841(pUA841) } \\
\text { UA831, 8091 or JAH60 } \\
\text { UA875(pUA875A)(pUA875B) } \\
\text { UA883(pUA883) }\end{array}$ & $\begin{array}{r}1.0 \times 10^{-4} \\
<1.0 \times 10^{-8} \\
4.0 \times 10^{-7} \\
1.2 \times 10^{-4}\end{array}$ \\
\hline $\begin{array}{l}\text { pUA883:pUOA23 } \\
\text { (SspI : SmaI }) \ddagger\end{array}$ & $\begin{array}{l}\text { UA833(pUA883) } \\
\text { UA875(pUA875A)(pUA875B) } \\
\text { UA831 or } 8091\end{array}$ & $\begin{array}{r}2.5 \times 10^{-5} \\
3.0 \times 10^{-7} \\
<1.0 \times 10^{-8}\end{array}$ \\
\hline
\end{tabular}

*Experiments were performed twice on BHI-YE agar. Transformation frequencies were determined by spotting $0.5 \mu \mathrm{g}$ plasmid DNA onto various recipient strains. Transformation frequencies were determined as described in Table 2.

$\uparrow$ The ligation mixture of EcoRI-cut pUA841 and pUOA23 was used as donor DNA.

¥The ligation mixture of SspI-cut pUA883 and SmaI-cut pUOA23 was used as donor DNA.

changes in modification of DNA in this strain rather than being due to deletion and/or rearrangements.

\section{Transformation with plasmid DNA}

Natural transformation of $H$. pylori plasmid DNA is summarized in Table 3. Plasmid transformants were never obtained with plasmid-free recipients using any of the ligation mixtures, purified DNA, miniprep DNA or crude cell lysates. When plasmid-containing strains, namely UA841(pUA841) and UA883(pUA883), were used as recipients, transformants were obtained at frequencies of approximately $1 \times 10^{-4}$ except for UA875(pUA875A)(pUA875B), which was a poor recipient for pUOA26 (Table 3). The results indicate that plasmid transformation in $H$. pylori can only occur when the recipient contains a plasmid with which the incoming plasmid can recombine. Therefore, it is likely that plasmid pUOA26 is more homologous to pUA883 than to pUA875A or pUA875B.

Transformation of pUOA26 into plasmid-free $H$. pylori was achieved by electroporation (Table 4). When the plasmid was transformed into the same strain from which it was isolated, the transformation frequency was approximately $1 \times 10^{-4}$ per viable cell. In contrast, when the plasmid was transformed into a different strain, the transformation frequency was reduced by more than 1000-fold.

Interspecies plasmid transformation was also tested. Plasmid pUOA26 could transform neither $E$. coli $\mathrm{DH} 5 \alpha$ nor $C$. coli UA585 to $\mathrm{Cm}^{\mathrm{R}}$. Plasmid pUOA23, which
Table 4. Electroporation of pUOA26 plasmid DNA in H. pylori

\begin{tabular}{llc}
\hline \hline Recipient & \multicolumn{1}{c}{$\begin{array}{c}\text { Transformation } \\
\text { frigin of } \\
\text { plasmid DNA }\end{array}$} & $\begin{array}{c}\text { per viable } \\
\text { cell* }\end{array}$ \\
\hline 8091 & 8091 & $1 \cdot 5 \times 10^{-4} \dagger$ \\
NCTC 11639 & NCTC 11639 & $1.5 \times 10^{-4} \dagger$ \\
NCTC 11639 & 8091 & $1.0 \times 10^{-7}$ \\
UA802 & NCTC 11639 & $<1.0 \times 10^{-8}$ \\
\hline \hline
\end{tabular}

* All experiments were performed using a voltage of $2.5 \mathrm{kV}$ and $25 \mu \mathrm{F}$, resistance in parallel corresponded to $600 \Omega$ with a time constant of $12.5 \mathrm{~ms}$ in $0.2 \mathrm{~mm}$ cuvettes. Each experiment was performed four times.

$\dagger$ This transformation frequency corresponds to $2 \times 10^{3}$ transformants $(\mu \mathrm{g} \text { DNA })^{-1}$.
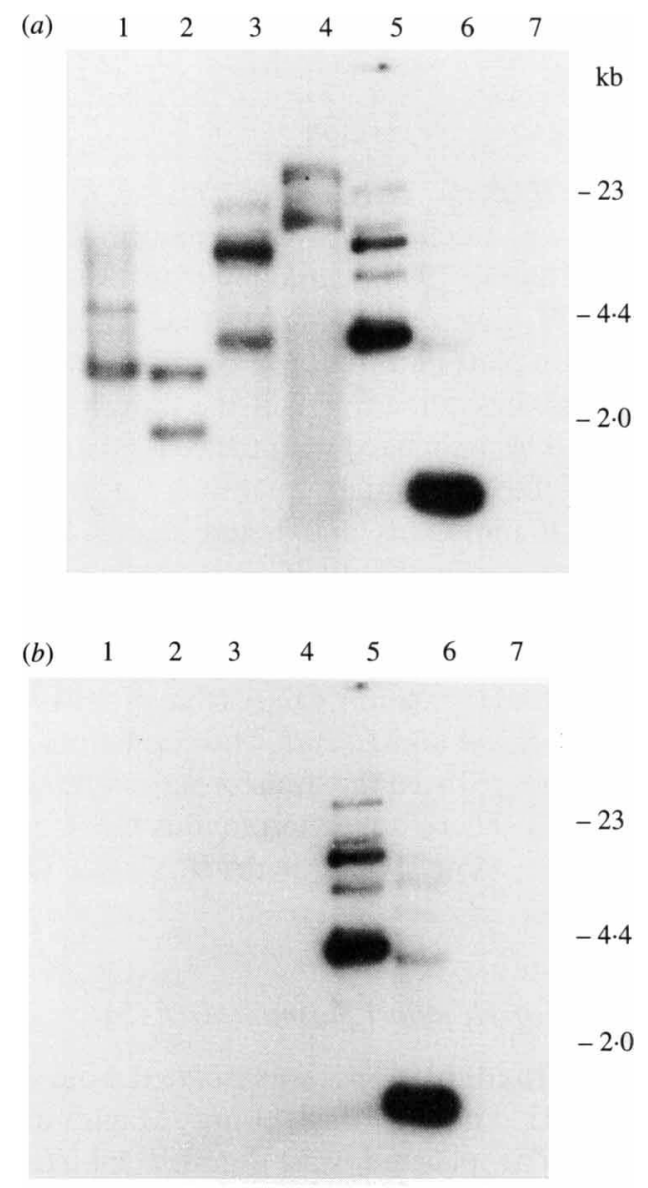

Fig. 4. Hybridization of pHPK255 to other $H$. pylori plasmids. (a) Membrane washed under low stringency conditions. (b) Same membrane washed under high stringency conditions. Lanes: 1, pUOA26; 2 , pUA841; 3, pUA875A and pUA875B; 4, pUA883:pUOA23; 5, pIHPK255; 6 , HindIII-cut pIHPK255; 7, HindIII-cut $\lambda$ DNA.

consists of an E. coli replication origin and a cat gene, and plasmid pUOA20, which contains a Campylobacter replication origin and the $c a t$ gene, also did not transform 
(a)

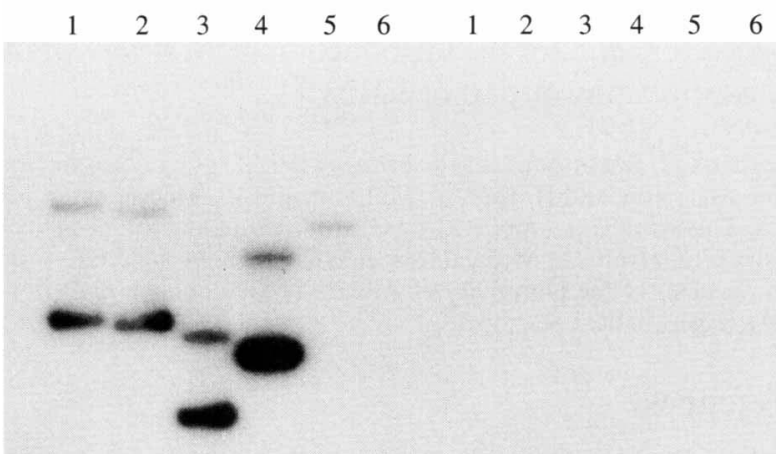

Fig. 5. Hybridization of pUOA26 to denatured $(a)$ or non-denatured (b) DNA. Lanes: 1, pUA841 inserted in pUC19 at EcoRI site isolated from $E$. coli $\mathrm{DH} 5 \alpha ; 2$, pUA841 inserted in pUC19 at HindIII site isolated from $E$. coli DH5 $\alpha$; 3, pUOA841 isolated from $H$. pylori UA841; 4, pUOA26 isolated from $H$. pylori $8091 ; 5$, pUA883 isolated from $H$. pylori UA883; 6 , HindIII-cut $\lambda$ DNA.

H. pylori 8091 or NCTC 11639 to $\mathrm{Cm}^{\mathrm{R}}$, either by natural transformation or by electroporation.

\section{Characterization of $H$. pylori plasmids}

The HindIII-cut $1.5 \mathrm{~kb} \mathrm{H}$. pylori plasmid pHPK255 (Kleanthous et al., 1991) was isolated from an agarose gel and hybridized to the $H$. pylori plasmids used in this study under low stringency conditions. All $H$. pylori plasmids, but not $\lambda$ DNA, hybridized to the probe (Fig. $4 a$ ). When the same membrane was washed under high stringency conditions, the probe remained hybridized only with itself (Fig. $4 b$ ). The results indicate that these plasmids share a certain degree of homology with pHPK255.

The deduced Rep protein of pHPK 255 has been shown to have similarities to the Rep proteins from a group of plasmids which replicate by the rolling-circle mechanism such as pADB201 from Mycoplasma mycoides subsp. mycoides and pLB4 from Lactobacillus plantarum (Kleanthous et al., 1991). The replication of these plasmids frequently involves single-stranded intermediates which can be detected by hybridization after Southern transfer under non-denaturing conditions (te Riele et al., 1986). No single-stranded DNA was detected in $H$. pylori cells harbouring either pUA883 or pUA841 and its derivatives (Fig. 5).

\section{Discussion}

This study demonstrates that $H$. pylori can acquire resistance to rifampicin and streptomycin, as well as to metronidazole, by natural transformation. Almost all $H$. pylori strains were naturally competent. Transformation of metronidazole resistance may have some clinical relevance, since it is one component of 'triple therapy'. This is the most effective regime for eradication of $H$. pylori from the gastric mucosa and consists of bismuth, metronidazole, and either amoxicillin and/or tetracycline (Borsch et al., 1988). Metronidazole resistance was found to develop rapidly in some patients who receive triple therapy (Rautelin et al., 1991). Natural transformation might contribute to development of antibiotic resistance by promoting acquisition by $H$. pylori of advantageous genes from other strains or from other species. However, transformation of a rifampicin resistance marker between $H$. pylori and $H$. mustelae, an organism isolated from the gastric mucosa and faeces of ferrets (Fox et al., 1992), was not demonstrated.

H. pylori produces large amounts of DNAase as reported by McNulty \& Dent (1987). It is not yet clear if this DNAase is extracellular or cell-membraneassociated and it may play a role in natural transformation, perhaps by processing DNA prior to uptake. However, the low percentage of radioactively labelled input DNA associated with transformed cells also appears to be a consequence of DNAase activity.

No DNAase ${ }^{-}$mutants of $H$. pylori have been reported to our knowledge. Therefore, this trait is likely to be advantageous to the host cells. The DNAase may be important in nutrition and it could also play a role in pathogenesis, since the DNAase could degrade any available DNA present in mucus covering the gastric epithelial cells, and thereby facilitate colonization. Although natural transformation of chromosomal DNA markers occurred in most $H$. pylori strains, natural transformation of plasmids was not demonstrated. This could be due to DNAase activity on plasmid DNA and/or restriction of incoming plasmid DNA.

Genomic DNA from $H$. pylori isolates displays considerable diversity in electrophoretic analysis in both pulsed field (Taylor et al., 1992) and conventional gels (Majewski \& Goodwin, 1988). Among the hypotheses put forward to explain this unusual genomic diversity is the production of various endogenous methylases with associated restriction endonucleases in different $H$. pylori strains (Taylor et al., 1992). These enzymes would methylate nucleotides within the recognition sequences for specific restriction endonucleases.

We found that $H$. pylori chromosomal DNA was resistant to digestion with $\mathrm{ClaI}$ and partially resistant to $E c o$ RI which indicates that DNA modification is occurring in $H$. pylori. Chromosomal DNA from $H$. pylori UA765, NCTC 11639, JAH60 and 8091 was also found to be resistant to digestion with Eco47111, HpaII, $M s p I$ and XhoI (N. Chang \& Y. Wang, unpublished results). Furthermore, the methylation systems are likely 
to be different among $H$. pylori strains, for example, DNA from $H$. pylori NCTC 11639 and JAH60 was resistant to $B c l$ I digestion, whereas DNA from $H$. pylori 8091 was completely digested by the same enzyme (N. Chang \& Y. Wang, unpublished results).

Additional evidence for the presence of unrelated restriction/modification systems in different $H$. pylori strains comes from our studies with pUOA26. This plasmid acquired some restriction sites but lost others after propagation in a different $H$. pylori host strain. Also, electroporation into the strain from which the plasmid was originally isolated was 1000 times more efficient than electroporation into a new host (Table 4).

The H. pylori plasmid pHPK255 contains DNA sequence found in plasmids which replicate through a rolling-circle intermediate (Kleanthous et al., 1991). Several $H$. pylori plasmids examined in this study (pUOA26, pUA841, pUA875A, pUA875B and pUA883) hybridized with pHPK255. Although no evidence of single-stranded DNA was seen on gels containing these plasmids, the notion that these plasmids also replicate via an asymmetric rolling-circle mechanism, cannot be ruled out. Plasmids, such as pUB110, which replicate via a rolling-circle mechanism but contain a minus origin, produce almost no detectable single-stranded DNA in either Staphylococcus aureus, its natural host, or in Bacillus subtilis (te Riele et al., 1986). Therefore, it is likely that the $H$. pylori plasmids we investigated also belong to the rolling-circle group of plasmids.

Only a few recombinant plasmids were obtained after $H$. pylori plasmid pUA841 was transformed into $E$. coli $\mathrm{DH} \alpha$. DNA from pUA841 experienced rearrangements or deletions. Similar observations were reported by Kleanthous et al. (1991) in cloning the $H$. pylori plasmid pHPK255 using pUC18 and E. coli JM105; however, in that case a single stable recombinant was obtained. Plasmid pHPK255, and probably also pUA841, replicates via the rolling-circle method and uses a singlestranded intermediate. When used as cloning vectors such plasmids sometimes display physical instability as the inserted fragments often carry fortuitous minus origins of replication and are prone to deletions and recombinational rearrangements (Gruss \& Ehrlich, 1989). Alternatively restriction/methylation systems discussed above could inhibit the stable inheritance of $H$. pylori DNA in some $E$. coli strains.

Plasmid-mediated antibiotic resistance had not been observed previously in $H$. pylori (Taylor, 1992). In this study, we demonstrated that a $C$. coli cat gene can be expressed in $H$. pylori. Plasmid pUOA26 containing the cat gene replicates stably in $H$. pylori 8091 , even in the absence of chloramphenicol selection, and no plasmidfree variants have been isolated after many generations of growth (K. P. Roos \& D. E. Taylor, unpublished data). This plasmid should be useful for further studies of restriction systems in $H$. pylori, and should provide important preliminary data for the construction of $H$. pylori vectors and for the introduction of $H$. pylori DNA for investigations of pathogenicity.

We thank H. Kleanthous for the probe pHPK255, C. L. Clayton for helpful discussion, and H. Lior, A. McLaren and J. A. Washington for strains. This work was supported by Glaxo Canada and a UniversityIndustry Grant from the Medical Research Council of Canada. K.P. R. was a recipient of the University of Alberta PhD Scholarship. D.E.T. is a Heritage Medical Scientist.

\section{References}

Birnboim, H. C. \& Doly, J. (1979). A rapid alkaline extraction procedure for screening recombinant plasmid DNA. Nucleic Acids Research 7, 1513-1523.

BoRSCH, G., MAI, U. \& OpferKuCH, W. (1988). Oral triple-therapy (OTT) may effectively eradicate Campylobacter pylori (C.p.) in man: a pilot study. Gastroenterology 94, A44.

Dick, J. D. (1990). Helicobacter (Campylobacter) pylori: a new twist to an old disease. Annual Review of Microbiology 44, 249-269.

Feinberg, A. P. \& Vogelstein, B. (1983). A technique for radiolabelling DNA restriction endonuclease fragments to high specific activity. Analytical Biochemistry 132, 6-13.

FoX, J. G., Paster, B. J., Dewhirst, F. E., TAylor, N. S., Yan, L.-L., MACUCH, P. J. \& ChMuRA, L. M. (1992). Helicobacter mustelae isolation from feces of ferrets: evidence to support fecal-oral transmission of a gastric helicobacter. Infection and Immunity 60, 606-611.

Gruss, A. \& EhrLICH, C. D. (1989). The family of highly interrelated single-stranded deoxyribonucleic acid plasmids. Microbiological Reviews 53, 231-241.

Kleanthous, H., Clayton, C. L. \& Tabaqchali, S. (1991). Characterization of a plasmid from Helicobacter pylori encoding a replication protein common to plasmids in Gram-positive bacteria. Molecular Microbiology 5, 2377-2389.

KNAPP, C. C., LudWIG, M. D. \& Washington, J. A. (1991). In vitro activity of metronidazole against Helicobacter pylori as determined by agar dilution and agar diffusion. Antimicrobial Agents and Chemotherapy 35, 1230-1231.

LIOR, H. \& PATEL, A. (1987). Improved toluidine blue-DNA agar for detection of DNA hydrolysis by Campylobacters. Journal of Clinical Microbiology 25, 2030-2031.

MAJEWSKI, S. I. H. \& GoodWIN, C. S. (1988). Restriction endonuclease analysis of the genome of Campylobacter pylori with a rapid extraction method: evidence for considerable genomic diversity. Journal of Infectious Diseases 157, 465-471.

MCNulTy, C. A. M. \& DENT, J. C. (1987). Rapid identification of Campylobacter pylori (C. pyloridis) by preformed enzymes. Journal of Clinical Microbiology 25, 1683-1686.

Miller, J. F., Dower, W. J. \& TOMPKINS, L. S. (1988). High-voltage electroporation of bacteria: genetic transformation of Campylobacter jejuni with plasmid DNA. Proceedings of the National Academy of Sciences of the United States of America 85, 856-860.

NedENSKov-SORENSEN, P., BuKHOLM, G. \& BOVRE, K. (1990). Natural competence for genetic transformation in Campylobacter pylori. Journal of Infectious Diseases 161, 365-366.

Rautelin, H., Seppala, K., Renkonen, O., Vainio, U. \& Kosunen, T. U. (1991). Role of metronidazole resistance in therapy of Helicobacter pylori infections. Antimicrobial Agents and Chemotherapy 35, 1230-1231.

te Riele, H., Michel, B. \& Ehrlich, S. D. (1986). Single-stranded plasmid DNA in Bacillus subtilis and Staphylococcus aureus. Proceedings of the National Academy of Sciences of the United States of America 83, 2541-2545.

SambrooK, J., Fritsch, E. F. \& Maniatis, T. (1989). Molecular Cloning: A Laboratory Manual, 2nd edn. Cold Spring Harbor, NY: Cold Spring Harbor Laboratory. 
Stewart, G. J. \& Carlson, C. A. (1986). The biology of natural transformation. Annual Review of Microbiology 1986, 211-235.

TAYlor, D. E., Hargreaves, J. A., NG, L.-K., Sherbaniuk, R. W. \& JEWELL, L. D. (1987). Isolation and characterization of Campylobacter pyloridis from gastric biopsies. American Journal of Clinical Pathology 87, 49-54.

TAYLOR, D. E. (1992). Genetics of Campylobacter and Helicobacter. Annual Review of Microbiology 46, 35-64.

Taylor, D. E., Eaton, M., Chang, N. \& Salama, S. M. (1992). Construction of a Helicobacter pylori genome map and dem- onstration of diversity at the genome level. Journal of Bacteriology $174,6800-6806$.

WANG, Y. \& TAYLOR, D. E. (1990a). Natural transformation in Campylobacter species. Journal of Bacteriology 172, 949-955.

WANG, Y. \& TAYLOR, D. E. (1990b). Chloramphenicol resistance in Campylobacter coli: nucleotide sequence, expression and cloning vector construction. Gene 94, 23-28.

Yanisch-Perron, C., Vieira, J. \& Messing, J. (1985). Improved M13 phage cloning vectors and host strains: nucleotide sequences of the M13mp18 and pUC19 vectors. Gene 33, 103-119. 